\title{
Literature as a Type of Performance
}

\author{
Cunjiu KUANG
}

College of Humanities, Sichuan Agricultural University, Ya'an, Sichuan Province, 625104, China

Keywords: speech act theory; literary performativity

\begin{abstract}
Literary performance, which has developed into a special theoretical concept in contemporary times, directly originated from the speech act theory proposed by John Langshaw Austin and John Rogers Searle. Later on, scholars such as Stanley Eugene Fish, Wolfgang Iser and Judith Butler massively expounded the theory of literary performance, based on the speech act theory. The theory of literary performance has brought about more conscious realization of the natures of performativity, expressiveness and communicativeness of literary creation, which acts as a vital opportunity for the gradual shift from the post-structuralist world as text to the post-theatrical world as performance and has exerted positive and important influence on the contemporary research of literary theory.
\end{abstract}

\section{Introduction}

Contemporary western literary theories contain large numbers of discussions concerning the concept and theory of performance. J. L. Austin (1911-1961) and John Rogers Searle (1932-), for example, in their speech act theory, hold that speeches are performances of acts, and, in literature, with strong performativity. In his theory of reader response criticism, Stanley Eugene Fish (1938-) believe that reading is an activity, a particular thing you are conducting; from a reader's perspective, he points out that text speeches act via readers. Wolfgang Iser (1926-2007) notes that what is significant is not what a literary text means, but what it does. Judith Butler (1956-), in her theory of gender performativity, holds that gender is formed through continuous performances. Hans-Georg Gadamer also believes that, literature is a variety of performance and exhibition, entailing necessary reader participation and interaction. All those discussions and expounding suggest that, literature as a type of performance has evolved into an independent discourse. This is indeed an interesting topic; this discourse theory, however, currently lacks macroscopic and holistic academic research in China. Therefore, theories or views relating to literary performance in recent years are classified and analyzed in this paper to contribute theoretically to the research and establishment of contemporary literary theories.

\section{Historic Review of Literary Discourse Performativity}

Wittgenstein's later view of language games is regarded as the ideological source of speech act theory, somewhat embodying theoretical elements of literary discourse performances. Nevertheless, performance, as a theoretical concept of contemporary literature discourse, directly originated from Austin's and Searle's speech act theory. Whereas Austin only admitted literary discourse as a parasitic and derivative discourse, his illustration of performativity of daily discourse directly promoted the appearance of literary performance discourse. He distinguished utterances as descriptive utterances and performative utterances, the latter of which contains elements of obvious performances. Searle's theory of literary performative learned from the idea of Wittgenstein's later view of language games; moreover, it inherited the theoretical view of "saying is doing" in Austin's speech act theory. In his view, fiction is a special language game. The peculiarity of fiction literature lies in that it includes another type of illocutionary acts (store telling, novel writing, poetry writing and drama writing. Compared with daily normalized discourses, fiction authors and narrators have their own complete set of illocutionary act expressions, which correspond to standard illocutionary acts, like questioning, requirements, commitments and description, and also supplement these standard illocutionary acts. Novels, dramas and poetry all display such strong performativity, 
especially drama texts. Nevertheless, playwrights do not often pretend to act inside, but pretend to perform through character roles in real performances. He points out that a fiction is a pretended reoccurrences of event; a drama, a played drama, however, is not a pretended reoccurrence of event, but the pretended event itself, which is the role the actor plays. Socioculturally, the literary performativity function creates concrete social reality and institutional facts, displaying obvious functions of creation, construction and practice. Searle's speech act theory and literary performance view have exerted significant influence on the contemporary western literary theories. Some scholars even hold that, the current academic trend is experiencing gradual shift from post-structuralist world as text to the post-theatrical world as performance.

The Chinese scholar Tao Jiajun holds that, both Wolfgang Iser and Judith Butler have benefited from the speech act theory and focused the performativity of culture. It is true that Iser's theory of aesthetic response criticism has included a number of elements such as game and performance, hugely affected by Wittgenstein, Austin and Searle's speech act theory. Tightly grasping the game and performance nature of speech act and expounding a series of innovative concepts such as boundary crossing, game and performance, Wolfgang Iser attempted to jointly analyze anthropology, linguistics and literature by using the concept of textual games, with the aim of discovering the anthropological connotations in literary fictions. From the perspective of anthropology, texts are essentially human beings' games of using languages in fictions and imaginations to experience and master the world, shown as a continuous performance activity of self-presentation and expansion. In textual games, readers proactively participate in imaginations and fictions, and, through various means, act on psychological activation factors of subject, awareness, society and history, leading to various schematic formations and expectation horizon, undoubtedly with obvious character and features of performance.

By comparison, Butler's theory of gender performativity is obviously with more characteristics of discourse performance. In her view, gender performativity is an act. If a gender is the target object of a particular person (yet never to be fully reached), the gender is a process of achievement or act. That is because gender carries non-natural attributes; it is created by action and is a product of literature and society, not something innate. For Butler, gendered body is also performative. Performativity and performance are interrelated and different, for which Butler distinguish the two concepts: performance and performativity. In her view, performativity constitutes reiterations of norms, and those norms pre-exist and restrict performers, which are neither the performer's wishes, selected fictions, nor a random play or theatric self-representation. She stresses that, performativity should not be understood to be single or purposeful actions, but reiterated and cited practice, with which the discourse acts on the body. 。 By contrast, performances cover up all hidden, undiscovered or non-performable objects; there must be a performer behind a performance, but for performativity, "there is no preexisting identity by which an act or attribute might be measured". Therefore, performativity can not be simplified as performance, since performativity has more complicated norms than a performer's performance, not determined by a wish or choice. It is wrong to equate performativity with performance. It is observable that Butler's gender performativity borrows the action connotation of performativity from Austin and Searle as well as ideas such as norm citation and reproduction from Derrida. The two concepts, that is, performance and performativity, can not be completely separated as well. Butler notices a number of overlapping points of the two. For example, "my theory sometimes waffles between understanding performativity as linguistic and casting it as theatrical. I have come to think that the two are invariably related, chiasmically". For her, theatricality is one of the two indispensable dimensions of performativity, and the representation during performativity is with noticeable theatricality, which is shown theatrically to and commented by the audience, as one form of performance. Butler holds that, gender performativity achieves re-thinking of psychoanalysis through the concept of performing; what the reader plays are those he/she selects. Undoubtedly, something unselected might also be significant. 


\section{Theoretical Connotations of Literary Performativity and Its Spiritual Features}

Literature, as a type of performance, displays the performance feature of literary discourse in its three acts: locutionary act, illocutionary act and perlocutionary act, which permeate through the three links and procedures: author's conception, writing and reader reception.

Performativity: In literature creation, the writer, when writing, needs to personally enter a state of writing and strives to enter the context of imagined reality. During this process, the writer's creative thinking, emotions and emotion, amongst others, are aroused and the author's thinking behavior is externalized as literary discourse. The writer's psychological motive, emotional attitude, behavior, actions, desire expressions are fully performed or expressed in words. Lu Ji vividly described this performativity of writer creation in his Essay on Literature: "Completely forbid hearing and seeing, concentrate the mind; let thought spread to everywhere and travel a vast distance. To its extremity, obscure thoughts turn clear and external objects appear continuously ...” It is even extraordinarily described in Liu Xie's The Literary Mind and the Carving of Dragons - Spiritual Thought or Imagination: "One who is engaged in literary thought travels far in spirit. Quietly absorbed in contemplation, his thinking reaches back one thousand years; and with only the slightest movement of his countenance, his vision penetrates ten thousand li; he creates the music of pearls and jade between his poetic lines, and he witnesses the rolling of wind and clouds right before his brows and lashes. These things are possible because of the work of imagination." When a writer composes, he/she deals with near and far, ancient and modern times, reality and virtual worlds; the images and appearances keep flashing in the mind, showing obvious performativity.

Image creation: Good literary works, such as poems, bring refreshment, rhythms and profound happiness. They encourage thoughts and create images and continuous rhymes. When reading a novel, the reader might get besotted and intoxicated with it; sounds and words of literary discourse echo in the mind, and schematic images uninterruptedly flash in the head; readers might exclaim in surprise for characters' fates and feel surprised at ups and downs in plots. The expressiveness and entertainment natures of reading behavior are fully displayed here. Both Heidegger and Gadamer stress that, each artistic work brings us an impact. When the point of sight shifts, the reader's perception, memory, imagination, interest, understanding, attention and psychological reception abilities, amongst others, may be aroused, with emotions and words accompanied by shrugs and frowns. Also, when the point of sight moves, the reader may cross a text, from one point of sight to another, forming overlapping of points of sight when they are connected.

Extensibility: The stretching force of literature is shown as an external or horizontal extension force of literary language, while literal force is as an internal or longitudinal impact of literary language. Chinese poems and lyrics focus the expression of stretching force, pursuing a status of implying meaning beyond words; operas and novels, by contrast, stress the expression of literal force, delivering complete meaning through words. Jakobson notes that, poems are organized infringement against and purposeful damages to common language, even enhancing effect by purposefully violating linguistic norms. It is pointed out in hermeneutics and receptional aesthetics that, texts are only unshaped semi-finished products; it is only through reading that literary works can construct their existence; it is only through interactions between texts and readers that the contents of works can be converted into images, meaning, value and aesthetic effects. A large number of blanks and gaps exist in text discourses, thus, requiring readers to compensate through their own experience, imagination and aesthetics and help the author to achieve it.

\section{Generative Mechanism of Literary Performance}

Literary performativity is generated during the production of literature. As a special speech act, literature is a kind of creative and productive activity under special background. That is to say, the generative mechanism of literary performance theory is constructed on the basis of speech act theory, also closely related to the Marxist literary production theory.

Literature is an art of language and also an aesthetic activity of creation and production. During this process, both the writer and the reader have blended into the works, with strong curiosity and 
expectation, eager to feel the beauty of linguistic form and learn about the outcome of subsequent storyline. The behaviorist and aesthetic natures of literature are important elements of literary performance. In literary creation, we can observe that the author sets up a bridge for communication and dialogue between locutionary act and perlocutionary act to achieve the effect of an illocutionary speech act so that the author's speech act can smoothly achieve its purpose. Literary creation is a normalized act as well as a conscious act; it is a conscious act conducted based on norms. We can notice that, the writer starts writing with observing creation principles and requirements for literary discourse, in terms of linguistic form, scenario design, image molding and model description. While fully immersed in creation, the writer blends norms into the background of creation to reach a flexible status. It seems that rules have been suspended, only under which can authentic literary works be created. Therefore, the writer's creation is an act observing certain rules yet not excessively restricted by them, as the realistic basis of literary performativity. In literary texts, however, the writer's multiple literary meanings are expressed. That is to say, in the literary text created by the writer, there is a large amount of what is similar to the illocutionary force defined in Searle's indirect speech act theory; those meanings beyond words require the reader to discover, imagine and interpret. Hence, the reader's understanding of deep behaviorist intent of literary discourse might be more diverse and complicated than his/her understanding of indirect speech act, subsequently leaving bigger space for exploration, imagination and interpretation. This is a process of meaning presentation as well as a process of performance of literary meaning. During reception, the entire literary works require the reader, as the writer does, to read in a way as if they were true and authentic. The reader, with a sincere attitude, accepts the rules established by the writer and enters the context of works to view and watch as an audience or get lost to intervene as a participant.

The reader may, based on his/her own experience, literary view and reading comprehensive ability, amongst others, have additional imagination, proactively reproduce in the mind the scenes, actions and plots of literary discourse act, and interpret the literary discourse differently based on his/her own situation. Filling in blanks and reproduction are also essential generative means of literary performativity. Such influence is, to both the writer and the reader, hidden and potential, but also profound and powerful. It may outdo the literary discourse itself sometimes, possibly affecting the attitude towards life, lifestyle and realistic behavior of writer and/or reader.

In all, literary performance has developed into a special theoretical concept in contemporary times; it directly originated from the speech act theory proposed by J. L. Austin and John Rogers Searle, which has been extensively expounded by contemporary western literary theorists such as Stanley Eugene Fish, Wolfgang Iser and Judith Butler. Literature is a special speech act. Literary creation differs from writing of daily discourse and also from researches of scientific discourses such as history or sociology. The theory of literary performance has brought about more conscious realization of the natures of performativity, expressiveness and communicativeness of literary creation, which acts as a vital opportunity for the gradual shift from the post-structuralist world as text to the post-theatrical world as performance and has exerted positive and important influence on the contemporary research of literary theory.

\section{References}

[1] Searle, J R. Express and Meaning: Studies in the Theory of Speech Acts [M]. Cambridge: Cambridge University Press, 1979: ??-??.

[2] Habermas, J. The Theory of Communicative Action Vol. 1: Reason and the Rationalization of Society [M]. Boston: Beacon Press, 1984: ??-??.

[3] He, C.Z. Judith Butler and Her Theory of Performativity [J]. Foreign Literature Review, 2010, (3): 132-143.

[4] Iser, W. Das Fiktive und das Imaginäre: Perspektiven literarischer Anthropologie [M]. Trans. Chen, D.J \& Wang, Z.L. Changchun: Jilin People’s Publishing House, 2003: ??-??. 
[5] Chen, X.G. Literary Language: Stretching Force of Language and Speech [J]. Nanjing Journal of Social Sciences, 2004, (2): 82-87.

[6] Liu Q. \& Yin, Z.K. On Communication of Fictional Discourse [J]. Journal of Huazhong University of Science and Technology, 2008, (1): 107-111. 